\title{
ROBERT B. HALL'S STUDIES ON JAPANESE RURAL ARCHITECTURE
}

\author{
Through a comparison with Bruno Taut's writings \\ ロバート・B・ホールの日本における農村建築研究 \\ ブルーノ・タウトとの比較を通して
}

Tyana SANTINI* and Takahiro TAJI**

サンティニティアナ, 田路貴浩

\begin{abstract}
During the 1930s, the American geographer Robert B. Hall and the German architect Bruno Taut made studies on Japanese rural architecture. This article examines the differences and similarities of these studies through a comparison of four particular points: (I) context and intentions, (II) approach to the study of rural architecture, (III) the study of habitation units, and (IV) characteristics found common to all Japanese rural architecture. The comparison showed that while Hall and Taut have the same understanding of the general characteristics of Japanese rural architecture, their disciplinary approach and different understanding of man's adaptation to the natural environment resulted in dissimilar explanations of the rural houses.
\end{abstract}

Keywords: Robert Burnett Hall, Bruno Taut, Geography, Japanese Rural Architecture ロバート・バーネット・ホール，ブルーノ・タウト，地理学,日本農村建築

\section{Introduction}

After Meiji Restoration (1868) several Western publications on Japanese architecture began to emerge. Initially, these works treated mostly religious and residential buildings, while the interest in rural architecture appeared only in the decades preceding World War 2. In this paper, the two most significant Western studies on Japanese rural habitation from the interwar period will be compared. The authors of these studies are the American geographer Robert B. Hall (1896-1975) and the German architect Bruno Taut (1880-1938).

At the time Taut's and Hall's studies were made, the academic research of rural architecture was only beginning. At these early stages of development, rural settlements were studied by scholars of several fields who approached the research in different ways and with different motivations. In Japan, one of the first scholars to be interested in rural settlements was Kunio Yanagita（柳田國男，1875-1962） who initiated the folklore movement in search of Japanese identity. In 1917, Yanagita founded the Thatch Group (白茅会) together with the architect Wajirō Kon (今和次郎，1888-1973) to document traditional Japanese rural houses ${ }^{1}$. Encouraged by the perceived loss of traditional culture caused by the introduction of Western influences, other folklorist associations appeared. The Green Reed Group（緑草会） made an important survey and classification of rural houses of Japan that was published in twelve numbers under the title Illustrated Minka (民家図集)2). The architect and city-planner Kenji Ishihara（石原憲治, 1895-1984) published an extensive study on rural houses focused in the regional differences and classification of houses by area ${ }^{3}$. Within the field of Geography, Takuji Ogawa (小川玩治, 1870-1941) investigated the form and distribution of rural houses within villages, Motoharu Fujita（藤田元春, 1879-1958) published the first comprehensive research on Japanese rural architecture history, while Hikoichirō Sasaki（佐々木彦一郎, 1901-1936) focused in the regional characteristics of rural houses ${ }^{4)}$

Among the studies made by Western authors on the same subject, Bruno Taut's work is undoubtedly the best known. During the three years that Taut was in Japan -from 1933 to 1936 - he was dedicated to the study of Japanese culture and architecture. His renowned writings have for long monopolized studies on the pre-war Western perception of Japan, and are still
* Doctoral Candidate, Graduate School of Engineering. Kyoto Univ., M. Eng.

** Assoc. Prof., Graduate School of Engineering, Kyoto Univ., Dr. Eng.
京都大学大学院工学研究科 博士後期課程・修士 (工学) 京都大学大学院工学研究科 准教授・博士 (工学) 
shaping Western ideas about Japanese architecture and culture.

On the other hand, Hall's studies on Japanese rural architecture still remain largely unknown despite their significance $^{5}$. During the 1920s and 1930s Hall made four summer field trips to Japan, and a prolonged research stay of one year during 1935-36. In those visits Hall conducted pioneer research on several regions of Japan. His writings on rural settlements are part of broader regional studies, which also consider the natural features of the area, the land division, and the agricultural activity. This larger context in which Hall's studies were made is one of the main reasons why they have been overlooked.

The grounds for the comparison of these dissimilar but related works are that both Taut and Hall analyzed a common subject (Japanese rural housing), performed field work in Japan during the same period (although they did not know each other, personally or professionally), based their studies primarily on their own field work, but within the frameworks of rather dissimilar disciplines. With these conditions in mind, the aim of the present comparison is to make clear how their different ideological and disciplinary contexts affected their studies on Japanese rural architecture.

To this end four particular points are compared: the context of their research and intentions when studying rural architecture (chapter 2), their approach to address the subject (chapter 3), how each author analyzed the habitation units (chapter 4); and the characteristics found common to all Japanese rural architecture (chapter 5). The comparison is based on the contents on Japanese rural architecture of the author's most relevant publications. In the case of Bruno Taut, the writings compared are drawn from his most popular work on Japan, Houses and People of Japan (1937), where he made the most extensive analysis of Japanese rural houses ${ }^{6}$. To support the examination of this text, previous analysis of Taut's writings on Japan were considered, particularly the works of Esra Akcan and Astrid Edlinger, who offer two different perspectives on the subject. Edlinger analyzes how Taut sees the changes during the modernization of Japanese architecture, while Akcan follows Taut's ideas on architecture from Germany to Japan ${ }^{7}$.

In the case of Hall, the evidence for the comparative analysis comes mainly from the articles Some Rural Settlement Forms in Japan from 1931, and Cities, Villages, and Houses of Japan from 19348). Contrary to Taut's works, Hall's publications on rural architecture have not been previously analyzed but the ideological and disciplinary context of his work was examined by the authors of this paper ${ }^{9}$.

\section{Context and intentions of Taut's and Hall's studies}

Taut's studies on Japanese rural houses are part of an examination of the county's architecture which is largely based on his personal experience ${ }^{10)}$. In Houses and People of Japan, Taut wants to show the "general tendencies and developments in Japanese architecture and its relation to Japanese civilization"1). His study of Japanese architecture is guided by the drive to prove that Japanese architecture responds to logical and understandable causes. Taut's intention to demonstrate that "strange and unaccustomed ways have very natural and simple reasons" is a reaction against Western claims, common at that time in popular publications, which portrayed Japanese architecture as exotic ${ }^{12}$. Taut's particular interest in rural houses comes from his understanding of the fundamental role of the farmers within the complex of Japanese culture. According to Taut, the culture of the farmer is "the true key to all Japanese culture up to the present day" since despite all changes in Japanese history the farmers were always the majority of the population, being in addition the only class that survived all cultural and social readjustments ${ }^{13)}$.

On the other hand, Hall's intentions when studying Japanese rural architecture are largely shaped by his academic discipline. The inclusion of habitation in geographic studies became a normal procedure after the works of the French geographers Jean Brunhes (1869-1930) and Albert Demangeon (1872-1940)14). These influential geographers understood that the man-made modifications of the land, as farming or settlements, were an integral part of the landscape and therefore their study was a necessary step in the geographic study of a region. In the United States, this idea was popularized by the renowned Carl O. Sauer (1889-1975), who helped redirect the subject of study of regional geographer's to this combination of natural and man-made elements known as the cultural landscape"15). As a disciple of Sauer, Hall intentionally laid an "overwhelming emphasis on settlements" because he understood that they summarized all the elements of the landscape ${ }^{16)}$. It was understood that the region's climate, natural resources, as well as the history and culture of its inhabitants were imprinted in the habitation. For example, the shape of the roof usually is related to the amount of rain or snow, while the materials of the house are normally those available in the region. The same way, the culture is embodied in the different spaces of the house that respond to the activities there performed, which in turn depend on the agricultural exploitation (for example determining the need for barns or poultry houses). The history of the region and its inhabitants can became apparent through certain formal features, as a roof-shape reminiscent of a foreign culture or through physical remnants of extinct activities as an unused mill. The non-material facts related to the cultural landscape - as the historical, political, and social aspects - were not a subject of study for the regional geographers, but they could borrow this type of information from other areas of knowledge to assist in the study of the landscape. 
Within this disciplinary context, Hall's purpose when studying rural architecture is to understand the house as to its interaction with the rest of the elements of the landscape, both natural and cultural.

\section{Approach to the study of rural architecture}

In order to support his argument that Japanese houses should not be regarded as exotic, Taut's chosen approach is the comparison between Japanese and European houses. Their resemblance is taken as the central theme from the beginning of the discussion. To demonstrate this resemblance, Taut presents Six pairs of photographs paralleling European and Japanese examples with very similar exterior appearance (Fig. 1). To confirm his observation on the similitude of these houses, Taut stated to have shown a several pictures of farmhouses from Europe to a Japanese person who would not believe that the houses were from other countries ${ }^{17}$.

Since the direct influence between the Japanese and European cultures at the time these houses were built was not a possible explanation, Taut speculates on the reasons for such resemblance. In his understanding, the similarities are related to a common human origin, suggesting that to find the causes of the similitudes of rural houses "researches (...) would have to go back to the remotest prehistorical ages, to the time of the first primitive creation of human language" ${ }^{18)}$. By referring to the common origin of all humans Taut is defying the accepted academic doctrines of his time - which denied the possibility of a shared ancestor of Indo-Europeans with people from other areas - in order to establish a link between the Japanese and the European cultures ${ }^{19}$.

At the time Taut made this research on Japanese rural architecture, the 1930s, the discourse of the vernacular types and the revival of traditional styles, as the Heimatstil, were becoming a political tool for the German nationalism. According to the analysis of Taut's writings made by Esra Akcan, Taut disapproves of this movement and instead wants to promote the study of architecture to disclose the principles of cosmopolitanism, not nationalism ${ }^{20)}$. For this reason Taut stresses that the Japanese farmer has kept "the equality of human production with an astounding fidelity and stand to-day as the truest witness that all men are brothers"21). Although the similarity of the houses paralleled in pictures is not further explained by Taut, in several occasions throughout his writings he makes reference to the fact that people have come to similar architectural results as a response to similar climates. When contrasting the different characteristics of the light and open Japanese construction with the secure and heavy walls of the houses in Ibiza, Taut explains how it is possible to see "the same process of reasoning operating everywhere, producing divergent results only as the consequence of varying local conditions,"

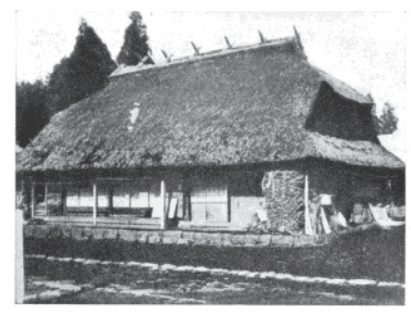

Fig. 176 Left: Japan

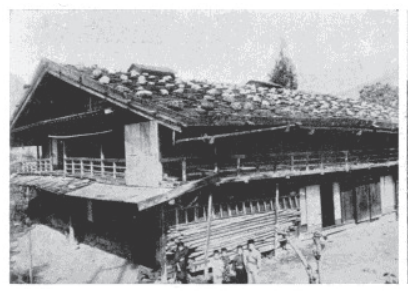

Fig. 179 Left: Japan

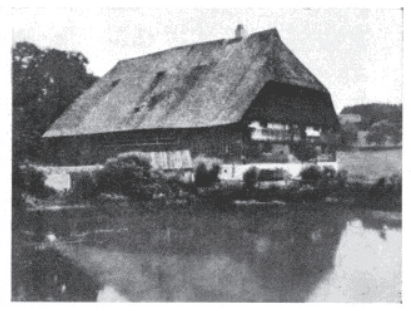

Right. Germany, "Schwarzwald" (Black Forest)

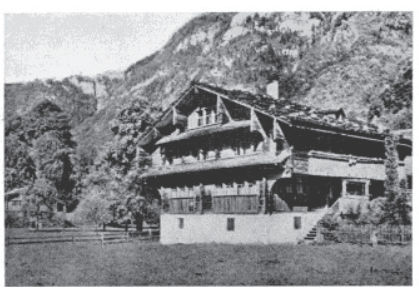

Right: The Balkans (Serbia)
Fig. 1 Taut's comparisons of Japanese rural houses (at the left) with European houses (to the right, Taut's original captions can be seen at the bottom of the pictures). Six pairs of houses are compared

adding that "farmers in Ibiza would act as logically as the Japanese and would undoubtedly live and build in Japan as their Japanese collegues (sic) do, just as the Japanese also would change their style on the Baleares in response to the different climatic conditions (...)"22). With this statements Taut does not imply that man and his culture are determined by the natural environment, but rather that men of different cultures arrive to the same logical conclusions because they are equally logical ${ }^{23}$. Therefore, although Taut considers an extensive array of factors when studying architecture including from history to ergonomics, he relies strongly on the natural conditions to base his explanations of rural architecture to back his argument of the equality of human production.

In opposition to Taut's convictions, Hall affirms that "different groups have adapted themselves in different ways in similar or in the same environment, and (...) that the same people, in different cultural stages, have reacted differently to the same environment"24). This statement does not intend to disregard the relationship between the man-made elements of the landscape and the natural environment. What Hall refers to with this account is to the impossibility of basing the explanations of any aspect of culture in the natural environment alone. To understand Hall's position it is important to point out that during this period the idea that a culture was determined by its natural setting was under debate within the field of Geography. The assumed unidirectional influence of nature on culture had led geographers to make mistaken generalizations, and even became associated with theories that explained the superiority of a culture over another. By the time Hall made his studies on Japan, most geographers (including him) had already abandoned these environmental deterministic ideas. Explanations of the 
man-made elements of the landscape were now based on a combination of natural and cultural facts. Therefore, when analyzing a region, Hall assigns great importance to the cultural and historical background of the area when explaining the landscape features.

Hall's particular interest in culture is apparent from the initial decisions of his analysis. When determining the boundaries of a region, geographers were usually guided either by natural limits or political divisions. In Hall's case, because of the emphasis he laid on culture, he opted to follow the ancient division of the country (Ryōseikoku, 令制国). According to Hall, the "cultural unity" was more closely bounded within these ancient provinces than to the prefectural divisions defined after Meiji Restoration, made to have an equitable distribution of natural resources among prefectures ${ }^{25}$.

Hall performed comprehensive regional studies in areas located throughout the country, each of them with dissimilar natural and cultural characteristics: Satsuma (now part of Kagoshima), Izumo (Shimane), Yamato (Nara), Echigo (Niigata), and Tokachi, in Hokkaido, area which maintains its ancient name. In the article Some Rural Settlement Forms in Japan, Hall presents the studies of the rural settlement of Satsuma, Yamato, Echigo, and Tokachi, while in Cities, Villages, and Houses of Japan he presents again the four types studied in the previous article, adding the Izumo and Shirakawa types.

One of the few guidelines available for the study of habitation within regional geography specified that one representative type of habitation should be established for each region. As explained by Brunhes and other writers, geographers should focus on the average - to be determined through a statistical study — and not on exceptional cases ${ }^{26}$. Hall follows this rule for most of the areas studied, but he makes two exceptions. The first one is for the area of Tokachi. This region of extreme cold winters was at that time being populated with incentives from the Japanese government. New settlers were coming from all over Japan, and in addition experimental farms were set after the plans of foreign advisers, particularly American ${ }^{27)}$. Each settler constructed the rural houses according to their tradition, resulting in a diverse cultural landscape for which Hall could not establish a representative type. While for each region studied Hall dedicates a section to the house type, in the case of Tokachi the section is entitled "Lack of Homogeneity in House Types"28). Hall explains the varied cultural influences reflected in the houses of Hokkaido, but the type chosen to be shown with illustrations is the house of the native Ainu, which was no longer the prevalent in the area but was the dwelling of the original inhabitants. The second exception that Hall made was to address the Shirakawa house. This habitation type is found only in certain valleys of Gifu and Toyama prefectures. Among the Japanese rural houses the Shirakawa type stands out because of their exceptional large size (having some of them up to five stories) and construction style. Because of the unique character of these houses, Hall presents only in this occasion a typology from an area for which no regional study was made.

This way, Hall establishes four typologies which are representative of a region (Satsuma, Izumo, Yamato, and Echigo) and, going against the standard procedures of Geography, he also addresses the exceptional cases of the Shirakawa and Ainu dwellings. Each rural house is examined case by case in relation to the region's characteristic natural environment and their different cultural and historical background.

\section{Explanation of house units}

Taut's discussion on Japanese rural houses addresses a generic type, focusing on specific features as roofs, fireplaces, or working areas. Because of his interest in the life and work of the farmer, Taut chooses to describe the elements of the house from an experiential point of view, assessing them as to their practical use and aesthetic qualities, and using these elements as means to describe the house (Fig. 2). Of the fireplace for example, which receives particular attention, Taut makes the following appreciation: "Farmhouses all over the world once had the same open fireplace as is found nowadays in Japan, (...) (t)he smoke fills the whole room and some skills is needed to sit at right angles to the fire so as to keep your eyes from watering. But as the hall of the farmhouse has no ceiling, the smoke rises freely up to the roof, blackening all the wood, (...)which (...) has a beautiful red-brown tinge (...)"29).

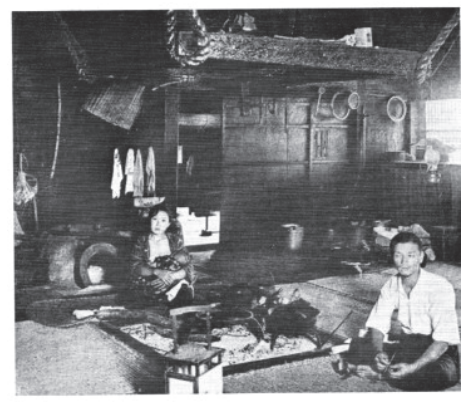

Fig. 2 Rural house in Shirakawa. Taut provides an insight of the life of the farmer in his dwelling

Taut's descriptions are not intended to provide a classification or an exhaustive display of Japanese rural houses since he was aware, as shown by his references, of the numerous Japanese works on the subject ${ }^{30}$. His explanations provide the reader with an insight of the life of the farmer and the routine of a house while describing its construction.

Also when discussing particular features of the house, Taut compares them with their counterparts in Europe, more specifically, with examples from Scandinavia. A Norwegian house from the $15^{\text {th }}$ century - shown in plan, section, and photographs - is presented by Taut to point out the similarity of 
the veranda projecting form the south side and the thick layer of earth with overgrown grass, which he recognizes as a feature often appearing in Japanese houses ${ }^{31}$. The Japanese corresponding features are not actually shown. In fact, the similitudes found by Taut are partial and do not have exact equals nor correspond to the same functions. For example, a similarity that interests Taut is the Swedish custom to keep the valuable goods in a separate building, as is done in Japanese houses. The construction of the Swedish storehouse is compared nevertheless to a Japanese Shinto shrine, and not with the Japanese storehouse. This fragmentary comparison process does not provide irrefutable evidence for Taut's arguments on humanity's shared logic, but conveys an identification between the European and Japanese cultures. Taut looks for familiar features in an environment that had been described as exotic to express the idea that there is certain common ground between the two cultures.

Meanwhile, Hall examines particular habitation types for specific regions. In all cases but Shirakawa and Tokachi, Hall samples several settlements before arriving at a conclusion of the average type. For example in the cases of Yamato and Satsuma Hall states to have surveyed twelve villages in each case before arriving at a conclusion ${ }^{32}$. The selected typologies are analyzed as the last step of a systematic study of the region. Beginning with the examination of the natural features and agricultural activity of the area, Hall then considers the distribution of villages and plot occupation, to conclude with the analysis of the house. Hall makes clear the interaction of all the elements of the landscape by showing their functional relations. For example, in the case of Yamato, Hall points out the connection between the main activity (rice production), the Han-den land division system imported from China, and the central location of the village within the paddy fields that allows the farmer to reach any point of the crops in few minutes to transport supplies and fertilizers. When analyzing the Yamato house, he presents a schematic facade and floor-plan accompanied by a brief description showing the arrangement of the house (Fig. 3). The house features that Hall considers are those that reveal the relation with the agricultural activity as the drying yards and storage rooms. The arrangement of these areas, which does not strictly depend on the agricultural activity, is explained by Hall to be a reminiscence of Chinese structures (Fig. 4) ${ }^{33}$ ). The organization of outbuildings around the drying yard in combination with the surrounding walls creates an enclosed space which is characteristic of the rural houses of eastern China ${ }^{34}$ ). Hall does not discuss in detail any specific feature of the house, as Taut does, but focuses on the distribution of areas and their relative position, in the horizontal organization of areas, as extending the geographer's interest in the aerial distribution of man activities on the land to the study of the house.

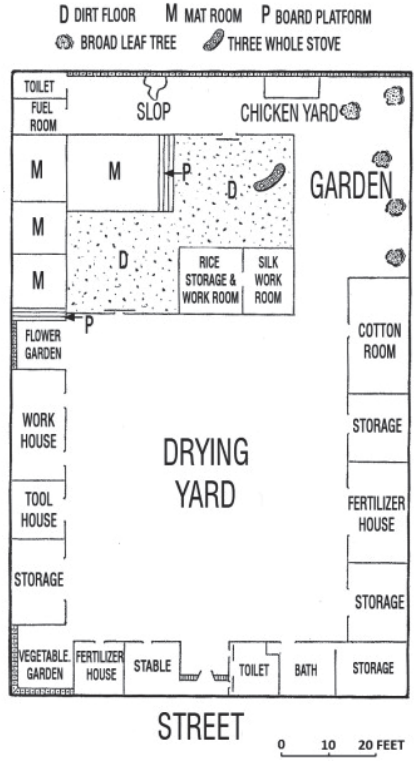

Fig. 3 Floor-plan of Yamato house type. The illustration shows the main house and outbuildings that enclose the drying yard

The materiality of the Yamato house is only briefly discussed. Hall makes a connection between materials and the weather, always present in geographic studies, but in this case is an indirect one. The deficiency of rainfall is explained to result in frequent fires, and therefore the materials of the house (as the thick plaster and the tin over-roofs) are said to respond mainly to this hazard. Being a geographer, Hall does not take note of the aesthetic features, nor discusses details of the life of the farmer. Contrary to Taut, Hall's writings maintain an academic distance from the subject of study, avoiding value judgments on Japanese society.

Another characteristic of Hall's studies is that, in agreement with his understanding of the variable influence of culture and nature on the settlements, the typologies are subject to an analysis with flexible parameters. For example, when analyzing Satsuma region, Hall states that its rural house is "a true product of its environment' ${ }^{\prime 35}$. In this case the natural factors as weather and available materials are predominant in the explanations. The rough thatch roofs of houses and detached storage rooms are explained to be a response to the warm weather of the area (Fig. 5) ${ }^{36}$. Still, cultural influences are also taken into account by Hall and the exterior appearance of the

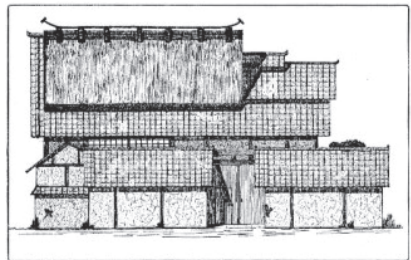

Fig.4 Yamato façade. Hal points out the Chinese influence shown in the surrounding walls and gate

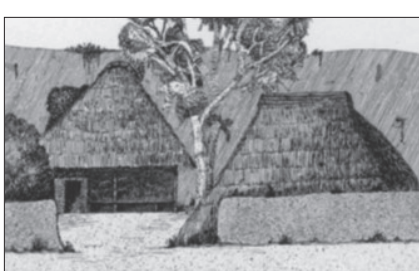

Fig.5 Satsuma façade. Hall points out the thatch roofs as mainly an adaptation weather conditions 
house is said to resemble those of the Loo-Choo islands (currently called Ryūkyū Islands, 琉球諸島) ${ }^{37}$.

The same way, the explanation of the Izumo type relies mostly on references to Korean influences, found by Hall in the shape of the roof-crest and the presence of a sacred tree at the front of every house (Fig. 6) ${ }^{38)}$, while the natural conditions play a secondary role on the explanations.

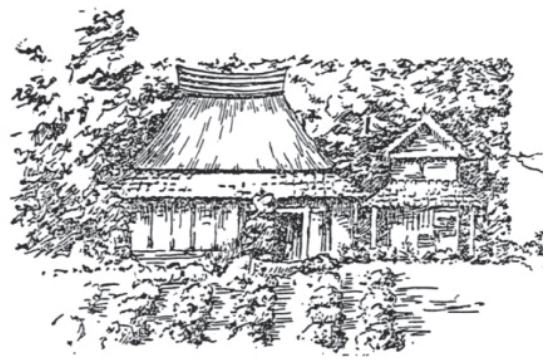

Fig. 6 Izumo façade. The shape of the roof-crest and front tree are associated with Korean houses

For the Echigo type, the weather is again the main factor in Hall's explanation. When describing the house Hall points out that " $(t)$ he roofs are of crude but heavy wooden shingles held in place by stones. The roof is asymmetrical with the shortest slope (...) facing the street (...) to retard accumulation of snow and to minimize the danger of snow falling from the roof"(Fig. 7) ${ }^{39}$ ). It is important to note that although Hall considers some features to be a response to the local conditions, he is careful not to imply that there is a single or better way of adapting to it, as Taut's comparative argument suggests.

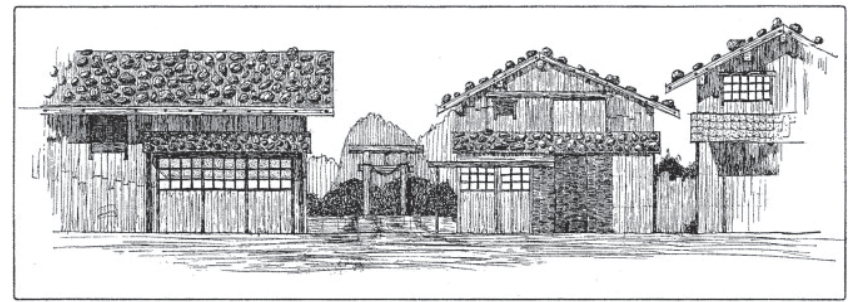

Fig. 7 Echigo façade. The strong and asymmetrical roof is explained to be a response to the heavy snow of the area

The representative types of housing found by Hall are either isolated rural houses or village houses. In the cases of Echigo and Yamato, the houses shown belong to rural villages, being this outcome most certainly a result of selecting the hose type out of a statistical average ${ }^{40)}$. As explained before, for the particular case of Tokachi, Hall discusses in general terms the variety of houses. In his understanding, the house type of Tokachi is "still in the experimental stage aiming to preserve the chief elements of Japanese culture and still afford comfort during the rigors of the long winter"41). Hall's appreciation of this situation as an experimental stage seems to indicate that he believes that at some point a particular type will be prevalent in the area, and that such type would be adjusted to natural as well as cultural conditions.
As done by Taut, Hall also relates Japanese habitations with those of foreign cultures, but in Hall's case the relationship is made only with cultures that have had a direct influence on the area. As a geographer, Hall considers these influences from the beginning of his analysis since the geographic proximity of other cultures is one of the factors to be considered in any study of the cultural landscape. By the time he arrives at the study of the house after analyzing the area, the foreign cultural influences have been already established when analyzing type of crops or land division, and these influences are therefore looked upon the house features.

Of the houses analyzed by Taut and Hall, only one receives attention from both authors: the house of Shirakawa. Although Taut refers mostly to a generic Japanese rural habitation, the houses of Shirakawa are singled out from the rest and examined at length. Similarly, Hall deviates from the procedures of regional geography to discuss this house type that he labels as "giant houses" (Fig 8)42). Both Taut and Hall are puzzled by the justification of this rural house so different from the rest. Taut tries to explain its origin by examining the construction. After a thorough description of the house, Taut states that "(o)ne might call this Gothic construction, concise according to (...) technique, economical in the use of wood and well-weighted in plan"43). Taut was particularly interested in the Shirakawa habitation because, in his understanding, they show "an absolutely logical and rationalistic construction in the manner of ancient Europe", which strengthen his argument on the shared logic of all humanity (Fig. 9) 44).

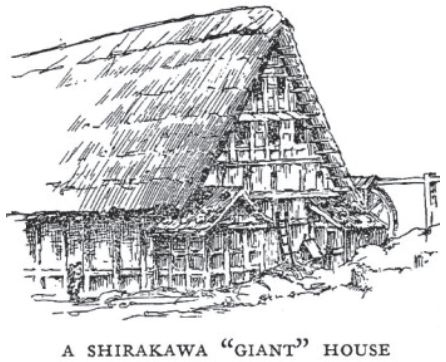

Fig.8 Illustration of Shirakawa "Giant" house included in Hall's article Cities, Villages and Houses of Japan, 1934

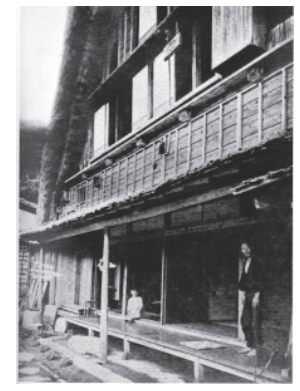

Fig. 9 Exterior of a Shirakawa house. Taut finds its construction logical and rational
On the other hand, Hall tries to explain the house with a combination of climatic and historical events stating that " $(t) h e$ great vertical development of these houses may be explained in part by the deep winter snows, the dearth of level land, and the fact that the aristocratic Taira wished seclusion and protection from the crude and somewhat savage natives which preceded him" ${ }^{45}$ ). The members of the Taira clan (also called Heish, 平氏, or Heike, 平家) established in the valleys of Gifu prefecture around the end of Heian period, and were believed to be linked 
with the origin of these distinctive houses ${ }^{46}$. The relation of the Shirakawa houses with this clan does not explain any particular feature of the construction, but this presumed relation (also mentioned by Taut) was at the time one of the few available postulates on the origin of these houses.

\section{Characteristics common to all Japanese rural houses}

Despite the differences in their studies, when considering common features of Japanese rural housing, Taut and Hall arrive at the same conclusions: (a) the Japanese rural house is adapted mainly to the summer weather, (b) the rural house is an implement of rice agriculture, and (c) in spite of great formal variation, Japanese rural houses have certain features that gives them an apparent unity.

(a) Taut and Hall recognize that the Japanese rural architecture is well suited for the summer weather, describing the houses using both the same terms: "lightly constructed" 47 ). They also point out that these houses are not prepared for the cold winters of the northern areas of Japan. The adaptation of the house to the natural environment is prevailing throughout Taut's explanations, and therefore the presence of these same lightly constructed houses in cold areas is for him the only remaining of the "great mysteries in regard to the climate", finding no explanation for this fact ${ }^{48}$. Hall, on the other hand, attributes the unsuitability of the house to colder areas to the fact that the Japanese rural house is still in a process of adaptation — as in the mentioned case of Hokkaido- because he understands the house as a result of a process of the constant interaction between culture and nature.

(b) The connection between the Japanese rural house and rice agriculture is naturally acknowledged by both authors, but they use this fact to clarify different things. Despite Taut's associations between Japanese and European houses, there are variances that he explains by stating that " $(t)$ he nature of the farm work, which is almost entirely confined to the cultivation of rice and mulberry-trees (...) explains all the differences from farmhouses elsewhere" ${ }^{\prime 49)}$. The differences pointed out by Taut, such as the small scale exploitation and the smaller amount of animal shelters unnecessary for the rice production, can be explained by the type of production. Hall, on the other hand, states that "as most farm families carry on a highly similar agriculture, the majority of rural habitations have many features in common", using the extended practice of rice agriculture as part of the explanation for the resemblance he finds among all Japanese rural houses ${ }^{50}$.

(c) Although Taut recognizes that "in particular regions one special type, which has stood the test of time, is often repeated"51), he finds more interest in the coexistence of different types of roofing, materials, and shapes within the same region. Still, within this diversity he notes a "peaceful union" that prevails despite variations ${ }^{52)}$. In Taut's words, in the varied styles "there is ever the same spirit which unites all the many variations and produces an aesthetic whole" ${ }^{53)}$. Taut does not discuss in detail such union, but the way he analyzes the rural houses focusing on common features and underemphasizing the differentiation of types (excepting for the case of Shirakawa) is consistent with his perception of unity.

Hall also perceives an overall uniformity in the Japanese culture that he finds represented in the farm houses, despite the establishment of different types by region ${ }^{54}$. Besides being partially a consequence of the same type of agriculture as explained before, Hall understands that the common origin of Japanese rural houses is also responsible for their resemblance. According to Hall, all Japanese houses have developed from "a thatch covered lean-to made of two crossed beams supporting a longer ridge pole and covering a shallow pit”, presumption that has been confirmed by post-WW2 archeological studies ${ }^{55}$. Following the considerations on the evolution, Hall describes the common features of Japanese houses as follows: "The basic house (...) seems to be a rectangular structure of three rooms. At one end is the dirt floored kitchen, which serves as the main entrance. (...) The middle room in the ancient house had a bare board floor and, although this later came to be covered with a matting, a narrow board platform persists on the kitchen side. (...) The floor of the third room is covered by thick woven mats, or tatami, which are of a standard size throughout Japan. (...) Sliding doors with light wooden frames, covered by shoji of thin rice paper, separate the rooms"56). This general description is the only occasion in which Hall talks about the interior features of the house since these types of architectural features were considered of secondary interest for the geographer.

\section{Conclusion}

Near the end of his study, Taut makes the following observation while assessing his own work: "I came to the conclusion that the practical work and researches of an author (...) are based entirely on his leading idea. (...) There must always be a selection. And that selection, as to material, methods and terms of reference, will be fixed by the point of view taken by the scholar"57). The differences in the studies on Japanese rural architecture compared in this article seem to confirm Taut's statement.

Taut's leading idea is to show that Japanese houses — called exotic by some Westerners - have in fact simple and logical explanations. His comparison between Japanese and European houses allows him to illustrate how both cultures have developed similar responses to similar environments ${ }^{58}$. From Hall's stand point, such comparison would act against his belief that cultures can adapt differently in similar environments. Hall addresses the relation of Japanese houses with foreign cultures only when 
there has been a direct influence as in the case of the China in the Yamato house, or Korea in the Izumo house. Therefore, the different understanding of how man adapts to nature makes Taut and Hall take different analytical decisions.

In addition, the authors here compared have different disciplinary contexts. For Taut, architecture is the center of his analysis and he is interested in the house features which he discusses from an experiential and aesthetic perspective. Hall, on the other hand, approaches the study as a regional geographer. Beginning with the examination of the region, he studies the house as the last step of the analysis and studies each case considering the interactions of the natural and cultural characteristics of the area. This method was not as usual for geographers of his time who were just beginning to integrate the man-made elements of the landscape to their studies. It has to be noted that although the concept of the cultural landscape as cohesive whole is currently widely spread, Hall's studies are pioneer in their way of integrating Japanese rural architecture to the geographical study of the region.

This analysis of Hall's studies provides an understanding of his approach within the framework of the Western ideological context, and brings forth its main characteristics through a comparison with the work of a renowned architect as Taut. This explanation of Hall's approach will allow to perform further research within different frameworks, as for example, the Japanese academic context of the interwar period. As compared to the studies made by Japanese scholars mentioned in the introduction, it can be said that Hall's approach combines the interest in form of Ogawa and the historical concern of Fujita. In addition, Sasaki and Hall quoted each other in their studies indicating a possible mutual influence of Japanese and American academic studies of rural settlements ${ }^{59}$, which is one of the many questions worthy of attention.

\section{Acknowledgements}

The authors would like to express their gratitude to Robert B. Hall's grandson, Robert Hall, for his kind support and for providing indispensable material for the investigation, and to Prof. Taisaku Komeie (from the Graduate School of Letters of Kyoto University) for his insightful feedback.

\section{Notes}

1) Wendelken-Mortensen, C.: Living with the Past: Preservation and Development in Japanese Architecture and Town Planning, MIT, Ph.D. Dissertation, 1994. 今和次郎：日本の民家：田園生活者の住家, 鈴木書店, 1922; 農村家屋の改善, 日本評論社, 1933 .

2）緑草会：民家図集，第 1 輯 山梨県-第 12 輯 長野県, 大塚巧芸社, 1930-1931.

3）石原憲治：日本農民建築，第 1 輯-第 16 輯, 1934 .

4）小川琢治：人[文]地理上より觀たる日本の村落，地球，Vol.4, No.5, pp.267-290, 1926. 藤田元春：日本民家史、刀江書院，1927. 佐々木彦 一郎：民家の形態に現れた地域の特性、地理学評論、Vol.7, No.9, pp. 757-764, 1931.
5) Hall's studies on rural architecture have been acknowledge as important but never analyzed. See for example 杉本尚次 : 民家研究の 展望, 人文地理, Vol.12, No.6, pp.541-561, 1960; Nishi, M.: Regional Variations in Japanese Farmhouses, Annals of the Association of American Geographers, Vol.57, No.2, pp.239-266, 1967.

6) Taut. B.: Houses and People of Japan, Sanseido, Tokyo, 1937.

7) Akcan, E.: "Bruno Taut's Translations out of Germany. Toward a Cosmopolitan Ethics in Architecture," in Lejeune, J. F. and Sabatino, M. (eds.): Modern Architecture and the Mediterranean: Vernacular Dialogues and Contested Identities, Routledge, New York, 2010. Edlinger, A.: "The Japanese Example-or the Art of Appropriation," in Herrle, P. and Wegerhoff, E. (eds.): Architecture and Identity, Münster, Lit Verlag, 2008.

8) Hall. R. B.: Some Rural Settlement Forms in Japan, Geographical Review, Vol.21, No.1, pp.93-123, 1931; Cities, Villages, and Houses of Japan, The Quarterly Review of the Michigan Alumnus, the University of Michigan, Vol. 40, No.17, pp.138-149, 1934.

9) Santini, T. and Taji, T.: Robert B. Hall's approach to the study of the Japanese Built Environment, Journal of Architecture and Planning (Transactions of AIJ), Vol. 79, No.702, pp.1799-1807, 2014.

10) Taut. B., op. cit., Foreword.

11) Ibid.

12) Ibid., p.70.

13) Ibid., p.101.

14) The study of habitation in the field of Geography started with the work of the founder of the modern French school of Geography, Paul Vidal de la Blache (1945-1918). The works of Brunhes and Demangeon, both disciples of Vidal de la Blache, were reference for geographers around the world. See for example: Demangeon, A.: La Picardie et les régions voisines, Armand Colin, Paris, 1905.

15) Sauer, C. O.: The Morphology of Landscape, University of California Publications in Geography, Vol.2, No.2, pp.19-54, 1925. The term Cultural Landscape - Kulturlandschaft - was first introduced by the German geographer Otto Schlüter (1872-1959) in 1906 in Die Ziele der Geographie des Menschen -Objectives of Geography of Man-, R. Oldenbourg, 1906.

16) Information taken from the records of the Round Table of the Association of American Geographers held at Syracuse, New York, December 1936, published as (no author): Round Table on Problems in Cultural Geography, Annals of the Association of American Geographers, Vol.27, No.3, pp. 155-175, 1936, p.167.

17) Taut, B., op. cit., p.105. The exact location of most of the Japanese houses shown in the comparative pictures is not specified by Taut.

18) Ibid., p.108.

19) The idea of the monogenesis of a proto-human language (proto-welt-sprache) and all subsequent languages descending from a single ancestral type had been abandoned during the late $19^{\text {th }}$ century, because of the myth of the Indo-Europeans were unrelated to any other family in the evolution line. This idea of monogenesis began to be considered seriously again only in the last decades of the $20^{\text {th }}$ century. For a detail discussion on the subject see Ruhlen, M.: On the origin of languages: studies in linguistic taxonomy, Stanford University Press, pp.122-136, 1994, p. 28.

20) Ackan, E., op. cit., p.203.

21) Taut, B., op. cit., p.108.

22) Ibid., pp.67, 68.

23) According to Astrid Edlinger's analysis of Taut's writings, the subject of the modern separation of man and nature was a concern for Taut, and through his practical and theoretical work he looks for a reconnection with nature. This inclination of Taut's thought might have encouraged his interest in rural habitation and the emphasis on nature in the explanations of such houses.

24) Hall, R. B.: The Geographic Region: A Resume, Annals of the Association of American Geographers, Vol.25, No.3, pp.122-136, 1935, p. 125.

25) Hall, R. B.: Cities, Villages, and Houses of Japan, op. cit., p. 139. 
26) This procedure had been established by Jean Brunhes who stated that for the geographer " $(t)$ hat which is exceptional has less value (...) than that which conforms more closely to a 'type", in Brunhes, J.: Human Geography. An Attempt at a Positive Classification Principles and Examples, Rand Mc. Nally\&Co., p.75, New York, 1920.

27) Davis, D. H.: Agricultural Occupation of Hokkaido, Economic Geography, Vol.10, No.4, pp.348-367, 1934.

28) Hall, R. B.: Some Rural Settlement Forms in Japan, op. cit., p.121.

29) Taut, B., op. cit., pp.111-112.

30) Taut refers for example to the work of Kenji Ishihara, from which he took a series of floor-plans. Taut, B., op. cit., p.116.

31) Taut, B., op. cit., p.111.

32) Hall, R. B.: Some Rural Settlement Forms in Japan, op. cit.,pp.101, 107.

33) Ibid., p.101.

34) Later, Ishihara K. makes the same comparison between houses of Nara and Chinese rural houses from Jinan area (济南市)。石原憲治 : 日本農民建築の研究，南洋堂書店出版部, 1976.

35) Hall, R. B.: Some Rural Settlement Forms in Japan, op. cit.,p.107.

36) Ibid., pp.107-108.

37) Hall makes the relation of Satsuma with the Loo Choo (or Luchu) islands through the article written by the renowned Chamberlain B. H.: The Luchu Islands and their Inhabitants (Concluded), The Geographical Journal, Vol.5, No.6, pp.534-544, 1895.

38) According to Kym Yulkyu (Prof. of the department of Literature of Inje University) these guardian tress can be still be found in the entrance of some Korean villages. From Kym, Y: Shamanistic Images in Korean Mythology, Koreana: Quarterly on Korean Art and Culture, Vol.6, No.2, pp.24-29, 1992.

39) Hall, R. B.: Some Rural Settlement Forms in Japan, op. cit., p. 116.

40) Some of the results of investigations made by Japanese scholars during the same period do not agree in the typology found average for the regions of Yamato (Nara) and Echigo (Niigata). For example, the typology selected as representative of Niigata by Ishihara Kenji (in 日 本農民建築, 聚楽社, 第 14 輯, 1934） corresponds to the isolated typology. Nevertheless, Hall's typology have been confirmed by the authors of this paper by a comparison made with the work the Green Reed group (Illustrated Minka from 1933 -民家図-see note 2) that confirms that Hall's selected typology for Niigata and Nara, are the types found in the villages.

41) Hall, R. B.: Some Rural Settlement Forms in Japan, op. cit., p.122.

42) Hall, R. B.: Cities, Villages, and Houses of Japan, op. cit., p.145.

43) Taut, B., op. cit., p.127.

44) Ibid.

45) Hall, R. B.: Cities, Villages, and Houses of Japan, op. cit., p.145.

46) Later research on Shirakawa houses, now categorized as Gassho-zukuri, do not mention the connection with the Taira (Heishi) clan and associate the particular arrangement and shape of the house with the requirements of the rural activities performed in the house. 新福 祐子：富山県の合掌住宅（第 1 報），家政学雑誌，Vol.26, No.3, pp.217-224, 1975 .

47) Taut, B., op. cit., p.95. Hall, R. B.: Some Rural Settlement Forms in Japan, op. cit., p.123.

48) Taut, B., op. cit., p.95.

49) Ibid., p.120.

50) Hall, R. B.: Cities, Villages, and Houses of Japan, op. cit., p 139.

51) Taut, B., op. cit., p.108.

52) Ibid., pp.108-109

53) Ibid.

54) Hall, R. B.: Cities, Villages, and Houses of Japan, op. cit., p 139.

55) Ibid. The source of Hall's data on the origin of Japanese houses is not known, but later research made by Japanese scholars confirms Hall's speculation on the origin of Japanese rural housing. See for example Ogawa, Tohru: "Geographical Distribution and Historic Development of Rural House Types in Japan, A Cultural Geography”, in Association of Japanese Geographers (eds.): Geography of Japan, Teikoku-Shoin,
1980.

56) Hall, R. B.: Cities, Villages, and Houses of Japan, op. cit., pp.139-140.

57) Taut. B., op. cit., p.252.

58) Taut does not imply that it is the natural setting which determines man's responses to it, but rather, that man of all cultures are equally logical and therefore they arrive at similar housing solutions. Taut's position is close to the concept of Probabilism, put forward by O. H. K. Spate in 1957, which is a mid-point between environmental determinism (ideology according to which culture is determined by nature) and possibilism (ideology according to which man and nature influence each other and is culture which creates the cultural landscape). According to probabilism, although nature does not determined culture, it sets constrains and limitations, and therefore there are certain responses that are more probable than others.

59) This connection has been noted, but not discussed, by Jinjirō Satō. 佐 藤甚次郎：日本における住居の地理学的研究の展開と成果（その2), 新地理, Vol. 15, No.1, pp.25-44, 1967-1968.

\section{Image sources:}

Fig. 1 Taut. B.: Houses and People of Japan, op. cit., pp.106-107.

Fig. 2 Taut. B., loc. cit., p.111.

Fig. 3 Hall, R. B.: Some Rural Settlement Forms in Japan, op. cit., p.101.

Fig. 4 Ibid., p. 100.

Fig. 5 Ibid., p. 106.

Fig. 6 Hall, R. B.: Cities, Villages, and Houses of Japan, op. cit., p.143.

Fig. 7 Hall, R. B.: Some Rural Settlement Forms in Japan, op. cit., p.114. Fig. 8 Hall, R. B.: Cities, Villages, and Houses of Japan, op. cit., p.145. Fig. 9 Taut, B., loc. cit., p.125. 


\section{和文要約}

本稿は、アメリカ人地理学者ロバート・B ホール (1896-1975) が 1930 年代に行った日本の農村建築に関する調査について、同時代 に同じテーマで行われたブルーノ・タウト（1880-1938）の調査と比 較しながら、その主な特徴を明らかにしようとするものである。比 較は下記の四つの点について行った。1）調査の背景と意図、2） 調查対象へのアプローチ方法、3）住居単位の研究方法、4）日本 の農村建築に共通すると考えられた特徵。

1) 研究の背景と意図

タウトの調查は建物に焦点が当てられており、日本建築をエキゾ チックなものと見るべきではないことを証明しょうとする動機に導 かれている。一方、地域地理学者であったホールは、文化的景観の 統合として農村建築に関心を持っていた。それゆえ、住居の調査を 地域の地理的分析に統合しようとした。

2）調查対象へのアプローチ方法

タウトは日本の農村建築はエキゾチックではないことを示すため に、日本とヨーロッパの類似する建物を比較している。そして、こ の類似性を説明し、全人類は同じ量の理性を備えており、そのため 類似する環境では類似の建物が現れると論じている。それに対して ホールは、薩摩、出雲、大和、十勝、越後、白川郷なじ、調査した 各地域においてそれぞれの代表的な類型を抽出している。それらは それぞれの地域の異なる環境と文化的背景に関連して説明されてい る。ホールはタウトとは異なり、異なる民族は類似する環境でも異 なる方法で適合することがあると考えていた。

3 ) 住居単位の説明

タウトは日本とヨーロッパにおける農村建築の固有の特徵、たと えば炉やヴェランダなどを断片的に比較し、それらを実用と美的性 質の観点から評価している。彼は両者の文化のあいだに共通する基 盤があることを示す類似の特徵を探索し、類似性は類似の環境の結 果であると説明している。

ホールの場合、分析は地域の農業活動の検討から始められ、住居 単位の調査が結論づけられている。彼は地域の構成とその相互関係 を検討し、土地における人間の諸活動の分布という地理学的関心を さらに住居の調查へと拡張している。その説明は自然環境と住居の 関係を考察してはいるが、外国からの文化的影響にも大きな重要性 を認めている。タウトとは反対に、ホールは中国や朝鮮などの例の ように、その関係が直接的である場合の夕諸外国との関係を認めて いる。

4）日本の農村建築に共通すると考えられた特徵

日本の農村建築に関して、ホールとタウトは異なるアプローチを 取ったにもかかわらず、日本の農村建築に共通寸る三つの特徴につ いて、両者のあいだに見解の一致が見られる。すなわち、（a）日本 の農村建築はおもに夏の気候に適応しているという事実、(b) 農村 建築は農業の手段であるという事実、（c）日本の農村建築は外観に 統一性をもたらす固有の特徴をもつということ。

結論

ホールとタウトの調査はそれぞれ異なるアプローチにもとづいてお

り、自然に適合する人間のあり方の理解はそれぞれ異なっている。 その結果、農村建築に対して異なる説明を与えることになった。タ ウトにとって、建築は彼の調查の中心であり、日本とヨーロッパの
住居の比較によって、類似する環境ではいかに類似の応答が現れて いるかを示そうとした。一方、ホールは農村建築研究を地域研究の 一部に含み、地域ごとに一つの代表例を見いだしている。各地域は それぞれ個別に検討され、住居と自然環境の相互関係が考察されて いる。包括的な全体としての文化的景観という考えは今日では一般 的になっているが、ホールの調查研究は日本において農村建築と地 域研究を統合するものとしては草分け的存在であると言えるだろう。

(2014 年 11 月 10 日原稿受理， 2015 年 3 月 25 日採用決定 